\title{
Coconut Fibre Effect on Fresh and Thermo Gravimetric Properties to Mitigate Spalling of Self-Compacting Concrete at Elevated Temperatures
}

\author{
Qahir N. S. AL-Kadi', Arabi N. S. AL Qadi²*, Kamal Nasharuddin Bin Mustapha ${ }^{3}$, \\ Sivakumar Naganathan ${ }^{3}$, Zakaria Bin Che Muda ${ }^{3}$ \\ ${ }^{1}$ Department of Earth Sciences and Environment, The Hashemite University, Zarqa, Jordan \\ ${ }^{2}$ Department of Civil Engineering, AL Hussien Bin Talal University, Ma'an, Jordan \\ ${ }^{3}$ Department of Civil Engineering, Universiti Tenaga National, Selangor, Malaysia \\ Email: ${ }^{*}$ arabi.alqadi@gmail.com, ${ }^{*}$ arabi@ahu.edu.jo
}

Received 3 June 2015; accepted 26 September 2015; published 29 September 2015

Copyright (C) 2015 by authors and Scientific Research Publishing Inc.

This work is licensed under the Creative Commons Attribution International License (CC BY).

http://creativecommons.org/licenses/by/4.0/

(c) (i) Open Access

\begin{abstract}
In this research the effect of Coconut (CN) fibre on the fresh and thermo gravimetric properties of self-compacting concrete (SCC) at elevated temperatures was investigated experimentally and statistically. The mixtures containing cement, water, fly ash, fine aggregate, coarse aggregate and super plasticizer with the addition of $\mathrm{CN}$ fibres $(0 \%, 0.05 \%, 0.10 \%$, and $0.15 \%)$ by volume of the mixtures were prepared. The fresh and thermo gravimetric properties of the SCC specimens were determined after mixing at elevated temperatures $\left(200^{\circ} \mathrm{C}, 400^{\circ} \mathrm{C}\right.$, and $\left.600^{\circ} \mathrm{C}\right)$ testing in a laboratory. Three control specimens with $0 \% \mathrm{CN}$ fibres were used for every mixture of SCC. Regression models were developed to determine the responses. The optimum of the $\mathrm{CN}$ fibres was measured.
\end{abstract}

Keywords

Coconut Fibres, Concrete, Hardened Density, Weight Loss, Compressive Strength

\section{Introduction}

Man has been amazingly resourceful when investigating materials to aid in his daily existence. Natural resources

${ }^{*}$ Corresponding author.

How to cite this paper: AL-Kadi, Q.N.S., AL Qadi, A.N.S., Mustapha, K.N.B., Naganathan, S. and Muda, Z.B.C. (2015) Coconut Fibre Effect on Fresh and Thermo Gravimetric Properties to Mitigate Spalling of Self-Compacting Concrete at Elevated Temperatures. Open Journal of Civil Engineering, 5, 328-338. http://dx.doi.org/10.4236/ojce.2015.53033 
have been extensively used and man is constantly looking for ways to further improve and develop these resources. CN fibre or coir is a product which is extracted from the outer shell of the coconut fruit. CN fibre is a fruit fibre that can be used in SCC to reduce the effect of fire in an accident and handle explosive spalling at elevated temperatures. Many researchers have studied using CN fibres as are enforcement of concrete, but there is a lack of studies concerning the use of this fibre in SCC to reduce the effect of explosive spalling under elevated temperatures when a building is exposed to fire in an accident. The need is to protect people and their property. These fibres present the following advantages: Renewable, non-abrasive, cheap, abundant and handling and processing causes less health and safety concerns.

The Singapore Engineer in 1976 [1] briefly described the influence of the incorporation of coconut husk fibres (Coir) on certain mechanical properties of concrete. The concrete prepared and tested was a coirfibre concrete. It was found that when tested for compressive strength, the coir had little influence. However, the tensile strength and modulus of rupture were increased significantly and the modulus of toughness of the beams was increased by up to $100 \%$.

Joseph Khedari et al. [2] investigated the use of a new lightweight construction material, composed of cement, sand and fibre from the waste of young coconut (Cocosnucifera) and durian (Duriozibethinus). Thermal conductivity, compressive strength and bulk density were investigated. The experimental investigation showed that the additions of these fibres reduced the thermal conductivity of the composite specimen and yielded a light weight material. The composite materials satisfied the basic requirements of construction materials, and they could be used for walls and roofs. Therefore, the potential for further development seems to be very encouraging. It could reduce the energy consumption of a building; the proposed materials offered an alternative option to dispose of the waste from the fruit industry.

Reis J. M. L. [3] studied the mechanical characterization of anepoxy polymer concrete reinforced with natural fibres which were investigated as part of his work to analyze the possibility of substitution by synthetic fibres. The natural fibres studied were coconut, sugar cane bagasse, and banana fibres. All of these fibres came from their specific products after they have been used, i.e. as recycled material. As the natural fibres were agricultural waste, manufacturing using a natural product became an economic and interesting option. The main idea was to use the fibres as they came from nature without any kind of preparation.

A comparison between epoxy polymer concrete reinforced with natural fibres, un-reinforced and reinforced with synthetic fibres was made. A brief description of how the natural fibres were obtained and the manufacturing process of polymer concrete was also made.

Guth et al. (1998) [4] pointed out that the occurrence of spalling in reinforced concrete (RC) structures using high-strength concrete must be prevented; it is well known that spalling is prone to occur under certain conditions, such as low water to cement ratios, high moisture content and exposure to an abrupt increase in temperature.

X. Liu, et al. (2008) [5] in their paper defined spalling as a phenomenon in which the surface of the concrete scales and then falls off from the structure along with an explosion at elevated temperatures.

Cheon G. H., et al. (2008) [6] investigated the effect of polypropylene (PP) and polyvinylalcohol (PVA) fibres on the spalling properties of high-strength concrete and the results showed that a fire test on the control concrete was explosive, and the specimens that contained more than $0.1 \%$ by volume of PP and PVA fibres did not suffer from spalling. The residual compressive strength ratio was higher than that of the control concrete before the fire test. This indicated that the addition of fibres into the concrete could increase the strength of the structure.

Hertz, et al. (2005) [7] devised a test method for determining the suffering of the actual concrete due to explosive spalling at a specified moisture level, taking into account the effect of stresses from progressive thermal expansion at the surface exposed to the fire. The study used cylinder shapes for testing, with different variations of concrete. It was concluded that sufficient quantities of polypropylene fibres (PP) with suitable characteristics may prevent spalling of a concrete sample even when thermal expansion is under restraint and can thuscanbe used in Self-Compacted Concrete (SCC) to prevent spalling when it is exposed to elevated temperatures, taking into consideration the characteristics of the SCC, and the different percentages of PP fibres under different conditions and elevated temperatures.

Fares et al. (2009) [8] [9] studied the performance of SCC subjected to high temperature. Two mixtures of SCC and one vibrated concrete were tested. Specimens were heated at different temperatures $\left(150^{\circ} \mathrm{C}, 300^{\circ} \mathrm{C}\right.$, 
$450^{\circ} \mathrm{C}$, and $600^{\circ} \mathrm{C}$ ) with an exposure time of one hour. They measured the mechanical (compressive strength, flexural strength, modulus of elasticity) and physical (water loss, density, porosity, and permeability) properties. They concluded that spalling occurs at $315^{\circ} \mathrm{C}$, and the compressive strength, flexural strength, and modulus of elasticity all decrease with an increase in temperature. Between $20^{\circ} \mathrm{C}$ to $150^{\circ} \mathrm{C}$, a small strength change was observed with no sensible degradation of the microstructure, merely the departure of bound water contained in the calcium silicate hydrate gel (C-S-H), and of free water contained in the concrete. From $150^{\circ} \mathrm{C}$ to $300^{\circ} \mathrm{C}$, an increase in compressive strength due to hydration of the anhydrous cement from the water movement, and cracks in the concrete within the paste for SCC were observed. At temperatures beyond $300^{\circ} \mathrm{C}$ the mechanical and physical properties decreased quickly up to $600^{\circ} \mathrm{C}$ at which point the mechanical properties became very weak, and the microstructure of the concrete deteriorated quickly. It was also observed that a chemical transformation took place due to the crystal change of the Brucite and the decomposition of the portlandite which produce more cracks, resulting in an increase in porosity of about $7 \%$.

This current research focuses on guidelines for the addition of constituent materials to the mixing proportions of SCC to enhance resistance to explosive spalling which occurs when standard SCC is exposed to fire in anaccident. This work investigates the workability of SCC after the addition CN fibres in percentages of $0.05,0.1$, and $0.15 \%$ by volume of the mix compared to plain SCC.

The objective of this current research is to investigate the fresh and thermo gravimetric properties and the improving potential of SCC containing $0.05 \%, 0.1 \%$, and $0.15 \%$ volume of $19 \mathrm{~mm}$ CN fibres in comparison with a plain SCC counterpart, and to establish regression models predicting the behaviour of the fresh and thermo gravimetric properties of SCC under elevated temperatures to mitigate spalling of SCC.

\section{Significance of the Research}

Many researchers have studied the use of CN fibres as reinforcement for the concrete but there is a lack of information about the use of this fibre in SCC to reduce the effect of explosive spalling under elevated temperatures when a building is exposed to fire. This information is significant to protect the lives of people and their property.

\section{Experimental Programme}

\subsection{Materials Used}

The following materials were used in this research:

1) Ordinary Portland Cement (OPC) was used in the investigation. The commercially available OPC was examined to ensure its various properties and proportions conform to (ASTM C150) [10]. This produced the following results: specific gravity (3.15) and fineness modulus $\left(2091 \mathrm{~cm}^{2} / \mathrm{gm}\right)$.

2) Coarse Aggregate or crushed angular granite material of $20 \mathrm{~mm}$ maximum size from a local source was used in the mixture. The following tests and results are listed: specific gravity (2.5), absorption (1.5\%), fineness modulus (6.05) and bulk density $\left(1480 \mathrm{~kg} / \mathrm{m}^{3}\right)$. The properties of this aggregate conformed to ASTM C 33 [11].

3) Fine Aggregates which consisted of river sand with a maximum size (4.75 mm), a modulus of fineness (3.0) at normal grading when added to the mixture resulted in a specific gravity (2.4) and an absorption value (6.4\%) [11].

4) Fly Ash (Class F) which contained less than 10\% lime (CaO), also known as low-calcium fly ash, was obtained as a by-product of electricity generation at the Kapar Thermal Power Plant Station, Selangor, Malaysia, which uses coal as a fuel. When this fly ash was added and used as are placement material for the cement in accordance with ASTM C 618 [12] the following results were obtained: specific gravity (2.323) and fineness modulus (2423 $\left.\mathrm{cm}^{2} / \mathrm{g}\right)$.

5) Super-plasticizer: A brown colour, free flowing liquid which had a relative density of 1.15 and its main purpose was to produce high strength concrete and create a flow ability which increases the slump flow of the SCC which corresponds to ASTM C 494 [13].

6) Mixing Water potable water was used conforming to British Standard [14] for mixing the concrete and curing of the reaction.

7) Coconut Fibre the fibrillated type used in this research consisted of one type of coconut fibre. Table 1 shows the physical properties of CN fibre [15]. 
Table 1. Mix design and fresh properties of the CN fibre.

\begin{tabular}{|c|c|c|c|c|c|c|c|c|c|c|c|}
\hline \multicolumn{12}{|c|}{ Mix design Used in Research } \\
\hline Mix No. & $\begin{array}{c}\mathrm{C} \\
\mathrm{kg} / \mathrm{m}^{3}\end{array}$ & $\begin{array}{c}\mathrm{FA} \\
\mathrm{kg} / \mathrm{m}^{3}\end{array}$ & $\begin{array}{l}\text { Water } \\
\mathrm{kg} / \mathrm{m}^{3}\end{array}$ & $\begin{array}{c}\text { Fine Agg. } \\
\mathrm{kg} / \mathrm{m}^{3}\end{array}$ & $\begin{array}{l}\text { Coarse } \\
\text { Agg. } \\
\text { kg/m }\end{array}$ & $\begin{array}{c}\text { Super } \\
\text { plasticizer } \\
\left(\mathrm{kg} / \mathrm{m}^{3}\right)\end{array}$ & $\begin{array}{c}\text { CN Fibre } \\
\text { (\%) } \\
\text { by vol. }\end{array}$ & $\begin{array}{l}\text { Slump } \\
\text { Flow } \\
(\mathrm{mm})\end{array}$ & $\begin{array}{l}\text { J-Ring } \\
(\mathrm{mm})\end{array}$ & $\begin{array}{c}\text { V-Funnel } \\
\text { (Sec.) }\end{array}$ & $\begin{array}{l}\mathrm{T} 50 \\
\text { (sec.) }\end{array}$ \\
\hline M0.0 & 437.5 & 120 & 178 & 907 & 730 & 8.1 & 0.00 & 730 & 663.5 & 7.8 & 4.2 \\
\hline M0.05 & 437.5 & 120 & 178 & 907 & 730 & 8.1 & 0.05 & 575 & 540 & 60 & 11 \\
\hline M0.10 & 437.5 & 120 & 178 & 907 & 730 & 8.1 & 0.10 & 535 & 495 & 180 & 22 \\
\hline M0.15 & 437.5 & 120 & 178 & 907 & 730 & 8.1 & 0.15 & 243 & 315 & 250 & 32 \\
\hline \multicolumn{3}{|c|}{ Length (L), mm } & \multicolumn{2}{|c|}{ Diameter (D), mm } & Aspec & atio (L/D) & \multicolumn{3}{|c|}{ Density $\left(\mathrm{g} / \mathrm{cm}^{3}\right)$} & & \\
\hline \multicolumn{3}{|c|}{19} & \multicolumn{2}{|c|}{0.04} & \multicolumn{2}{|c|}{475} & \multicolumn{3}{|c|}{$1.12-1.15$} & & \\
\hline
\end{tabular}

\subsection{Sample Preparation}

In the concrete production, the ingredient materials were firstly mixed with the superplasticizer and without fibres. The fibres were then added in small amounts to avoid fibre congestion and to produce a concrete with a uniform material consistency. For concrete mixes with a $0.15 \%$ volume of fibres, extra time was required for mixing. The freshly mixed CN fibre concrete was placed in mixer to cast a standard cylindrical $(75 \times 150 \mathrm{~mm})$ mould concrete specimen for the physical property tests. Hardened density was measured before the test was complete. With respect to the cylinders, each layer was consolidated without using any vibration. At the end of 24 hours after casting, the specimens were remoulded and submerged in a clean water pond at $20^{\circ} \mathrm{C}$ until the testing was complete (90 days). Figure 1(a) shows the CN fibres that were used in the research.

\section{Preparation of Coconut Fibre}

Coconut was bought from the available market and the husk was removed with all the fibres. These fibres were then separated and cut into small pieces, each with a length of $19 \mathrm{~mm}$ to be added to the SCC mixture. Figure 1 (a) shows the length of the fibre and its texture.

\section{Mixture Proportions}

All concrete mixes were prepared in 40-L batches in a rotating planetary mixer. The batching sequence consisted of homogenizing the sand and coarse aggregate for 30 seconds, then half of the mixing water was added to the mixture and then mixed for one minute. The mixture was then covered to minimize the evaporation of water and to let the dry aggregates absorb the water. After 5 minutes the cement and fly ash were added to the mixture then mixed for another minute. Finally, the super-plasticizer and the remaining half of the water were added and then mixed for another 3 minutes before the $\mathrm{CN}$ fibres were added gradually for an extra two minutes to formulate the SCC mixture. The total processing time was 11 minutes. Table 1 shows the mixing proportions and the fresh properties of the SCC.

\section{Test Methods}

\subsection{Fresh Properties of SCC}

\subsubsection{Slump Flow Test}

The consistency and workability of the SCC was evaluated using a slump flow test. The procedure of the test is as follows; dampen the slump cone and plate. Place the plate on firm, level ground. Centre the slump cone on the plate and hold down firmly. Fill the slump cone in one lift. Do not apply any external compaction effort. Strike off any excess concrete above the top of the slump cone. Remove the slump cone by lifting it vertically upward, being careful not to apply any lateral or torsional motion. Then measure the time for the concrete to spread to a diameter of $500 \mathrm{~mm}\left(\mathrm{~T}_{50}\right)$ and measure the final slump flow in two orthogonal directions after the concrete has ceased flowing. Due to its ease of operation and portability, the diameter of the concrete flowing 


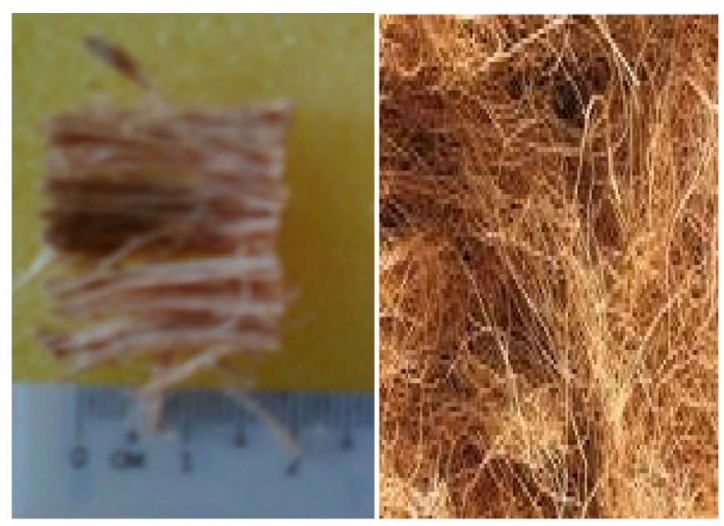

(a)

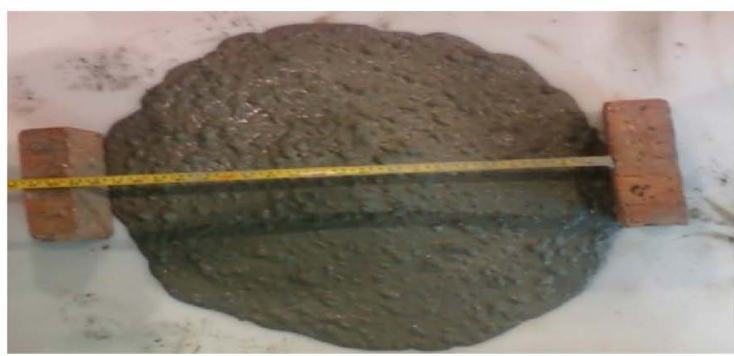

(b)

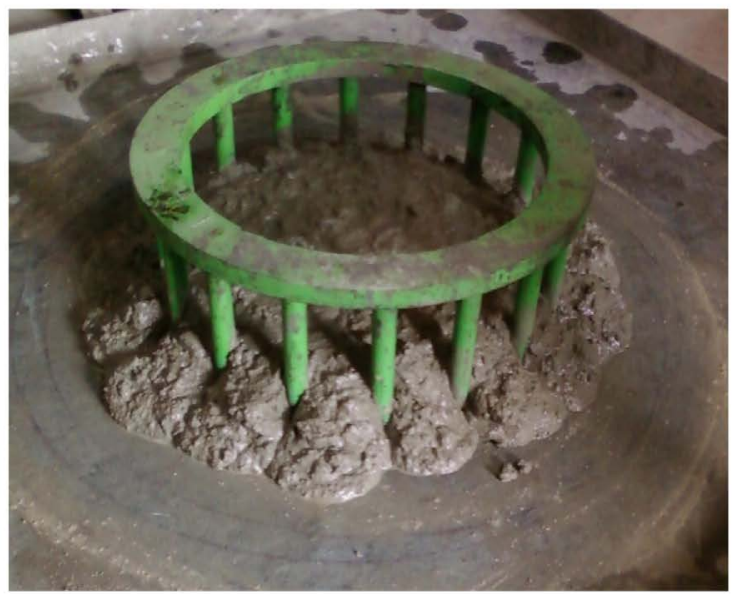

(c)

Figure 1. (a) Coconut fibre length and texture, (b) Slump flow test measurement, and (c) J-Ring test after removing the slump cone.

out of the slump cone was obtained by calculating the average of two perpendicularly measured diameters for determining consistency and workability. Thus, the SCC was assumed to have superior consistency and workability after gradually adjusting the chemical admixtures into the mix. Slump flow, $\mathrm{T}_{50}$ tests were used to test the filling ability of the SCC according to (ASTM C 1611) [16]. Figure 1(b) shows the slump flow test.

\subsubsection{J-Ring Test}

J-Ring is an excellent test for the passing ability of SCC. An inverted slump cone is placed inside the J-Ring and after the cone is lifted the height difference of the concrete between the inside and outside of the ring is measured. This distance should be less than $100 \mathrm{~mm}$ in order to prevent blockage from occurring [17]. Figure 1(c) shows the J-Ring test. 


\subsubsection{V-Funnel Test}

This is a test that also evaluates the flow of SCC and in this test the SCC mixture is tested by placing a V-Funnel frame on firm, level ground and positioning the bucket below the opening in the V-Funnel, dampening the inside of the V-Funnel, leaving the bottom gate open for a sufficient time so that once the gate is closed, water does not drain and collect in the gate, closing the bottom gate, filling the V-Funnel with concrete and being careful not to apply any external compaction effort. The next step is to strike off any excess concrete above the top of the V-Funnel and allow the concrete to remain undisturbed in the V-Funnel for one minute. Finally the gate of the V-Funnel is opened and the concrete allowed to flow into the bucket. Then the time from the opening of the gate to the point when light is first visible through the bottom hole is measured with an estimated emptying time of 6 to 12 seconds. The V-Funnel test is also used to assess the suitable amount of super-plasticizer [17].

\subsection{Physical Properties of Self-Compacting Concrete}

\subsubsection{The Weight Loss}

The weight loss test was performed on the average of the specimens tested at elevated temperatures of $200^{\circ} \mathrm{C}$, $400^{\circ} \mathrm{C}$, and $600^{\circ} \mathrm{C}$ and was compared with the control specimens at normal temperature in the laboratory on plain SCC and with different volume fractions of CN fibres in samples with the standard test cylindrical shape.

\subsubsection{Density of SCC}

Density $(\rho)$ is measured in $\mathrm{kg} / \mathrm{m}^{3}$, and the weight loss as a percentage. The specific volume was measured as a percentage of the reciprocal of the hardened density before exposing the specimens to elevated temperatures and also after the elevated temperature test was done. The density was measured from the mass of a specimen relative to the volume for each specimen tested for plain SCC and SCC with different percentages of CN fibres of the SCC mix design after the temperature test at room temperature.

\section{Results and Discussion}

The SCC test results in Table 1 through 7 were present the mixture fresh and thermo gravimetric properties of concrete with and without $\mathrm{CN}$ fibres. Each of the results of the tests for fresh, mechanical and physical properties were averaged over 48 test specimens. The slump flow, $\mathrm{T}_{50}$, J-ring, $\mathrm{V}$-funnel, weight loss, hardened density, specific volume, compressive strength, residual compressive strength were investigated for their response and independent variable effect of $\mathrm{CN}$ fibre by volume fractions at elevated temperatures.

\subsection{Fresh Properties}

Slump flow, $\mathrm{T}_{50}$, V-Funnel, and J-ring tests were performed according to the EFNARC Committee [18] procedure. Slump flow, and $\mathrm{T}_{50}$, tests investigate the filling ability of SCC with and without CN fibres that flow freely without unrestricted deformability. The J-ring flow test indicates the passing ability which restricts deformability of SCC with and without CN fibres due to the blocking effect of reinforcement bars of concrete. The V-funnel flow indicates the filling ability of SCC with and without CN fibres. Table 1 shows the percentages of $\mathrm{CN}$ fibres and the slump flow, $\mathrm{T}_{50}$, J-ring, and $\mathrm{V}$-funnel tests used in the research.

Figure 2 shows the relationship between $\mathrm{CN}$ fibres and slump flow. With an increase in the percentage of CN fibres, there is a decrease in slump flow which is related to the existence of the fibre that can increase the friction between the flowing concrete and the surface of contact in the slump flow test. There is a good correlation coefficient $\left(\mathrm{R}^{2}\right)$ 85.1\% for $\mathrm{CN}$. While, for the $\mathrm{CN}$ fibres against the $\mathrm{T}_{50}$ of the slump flow, the time increased with an increase in the percentage of CN fibres. The $\mathrm{R}^{2}$ is $99.7 \%$ which is ideal. Furthermore, the CN fibres with respect to the V-Funnel test showed an increase in the time to empty the V-Funnel as the percentage of CN fibres increased and the correlation coefficient $\left(R^{2}\right)$ equalled $98.1 \%$. Further, for the J-Ring test, as the percentage of CN fibres increased the J-Ring flow increased then decreased, with an $\mathrm{R}^{2}$ of $81.3 \%$. Which showed that an excess of fibre with a chemical reaction was found to absorb water because of the wood properties of CN fibre in the mixture.

\subsection{Physical Properties of Self-Compacting Concrete}

\subsubsection{Weight Loss}

The change in weight at elevated temperatures was measured on SCC made with ordinary Portland cement, 

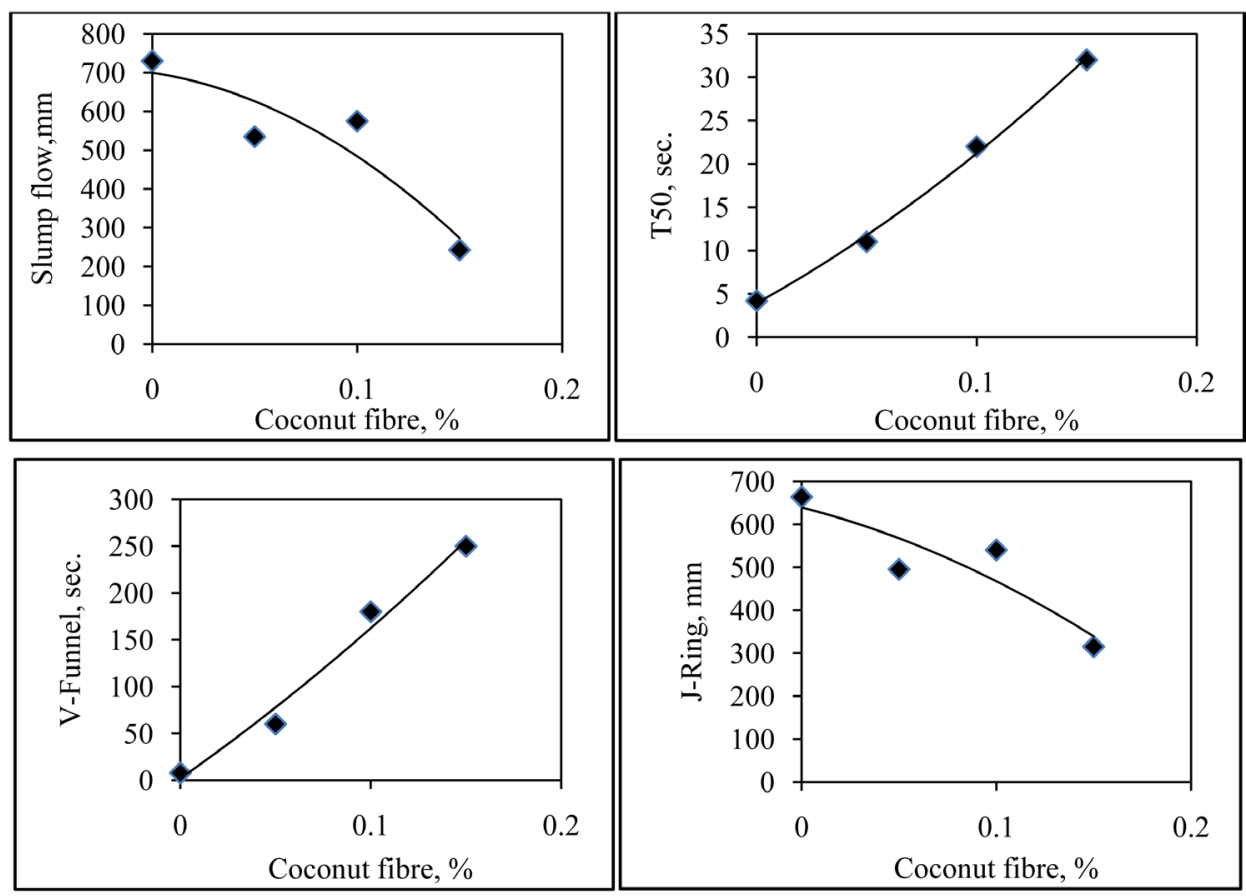

Figure 2. Relationship between CN fibres and fresh Properties of SCC.

granite aggregate, river sand, fly ash and super plasticizer with and without CN fibres at temperatures up to $600^{\circ} \mathrm{C}$. The test specimens were concrete cylinders of $75 \mathrm{~mm}$ diameter and $150 \mathrm{~mm}$ length stored at $20^{\circ} \mathrm{C}$ and soaked in water for 89 day. The tests were carried in a furnace for a time of exposure of 2 and 4 hours and fixed temperatures of $200^{\circ} \mathrm{C}, 400^{\circ} \mathrm{C}$, and $600^{\circ} \mathrm{C}$, respectively. The results are shown in Table 2 and Figure 3 and interpreted as follows:

Below $200^{\circ} \mathrm{C}$ there was a loss of weight due to evaporation of water from capillary voids which represented the space not occupied by hydrated cement in the hydration process. At $200^{\circ} \mathrm{C}$ the loss for the plain SCC was $5.79 \%$, and at $0.05 \%, 0.10 \%$, and $0.15 \%$ volume fraction of $\mathrm{CN}$ fibres the losses were $6.76 \%, 5.71 \%$, and $5.4 \%$ respectively. Also, the $\mathrm{CN}$ fibres burn at low temperatures to create channelization and voids to release the excessive vapour pressure in the paste and mitigate explosive spalling in the SCC.

From $200^{\circ} \mathrm{C}$ to $400^{\circ} \mathrm{C}$ the weight loss continued due to a loss of water from the gel pore and from the breakdown of the Tobermorite gel, and also from the decomposition of $\mathrm{CN}$ fibres at $350^{\circ} \mathrm{C}$ to $600^{\circ} \mathrm{C}$. At this stage the losses were found to be $9.77 \%$ for the plain SCC and the different CN percentages showed losses of $9.88 \%(0.05 \%$ volume fraction), $9.16 \%$ ( $0.10 \%$ volume fraction) and $8.60 \%$ ( $0.15 \%$ volume fraction). Between $400^{\circ} \mathrm{C}$ to $600^{\circ} \mathrm{C}$ the rate of loss in creased due to the decomposition of calcium hydroxide in the cement paste and also the decomposition of the Ettringite C-S-H phase, this state was followed by the formation of Dicalcium silicate $\left(\mathrm{Ca}_{2} \mathrm{SiO}_{4}, \beta-\mathrm{C}_{2} \mathrm{~S}\right.$, Belite). These were compared with the results of Schneider (1982) [18], and Harmathy and Allen (1973) [19].

The weight loss development of the SCC with CN fibres versus temperature appears in Table 2 and Figure 3 , showing that the weight loss of plain SCC concrete was $5.79 \%, 9.77 \%$ and $12.88 \%$ at $200^{\circ} \mathrm{C}, 400^{\circ} \mathrm{C}$, and $600^{\circ} \mathrm{C}$ respectively. The SCC concrete containing CN fibres provided an improvement at each volume fraction of CN fibre. The improvement, as the weight loss-effectiveness in Table 2 indicates, were $16.8 \%, 1.1 \%$ and $-13.4 \%$ for the $0.05 \%$ fraction over $200^{\circ} \mathrm{C}, 400^{\circ} \mathrm{C}$, and $600^{\circ} \mathrm{C}$ respectively. For the $0.10 \%$ fraction the results were $12.3 \%,-4.3 \%$ and $-19.3 \%$ for the $0.10 \%$ fraction over $200^{\circ} \mathrm{C}, 400^{\circ} \mathrm{C}$, and $600^{\circ} \mathrm{C}$ respectively. Lastly, the $0.15 \%$ fraction gave results of $-6.7 \%,-12 \%$ and $-20.8 \%$ at $200^{\circ} \mathrm{C}, 400^{\circ} \mathrm{C}$, and $600^{\circ} \mathrm{C}$ respectively, being a small reduction compared to the maximum weight loss for the $0.15 \%$ fraction. The weight loss reductions of SCC concrete with CN fibres ranged from $16.8 \%$ to $-6.7 \%, 1.1 \%$ to $-12 \%$, and $-13.4 \%$ to $-20.8 \%$ for the volume fractions of $0.05 \%$ to $0.15 \%$, and temperatures of $200^{\circ} \mathrm{C}$ to $600^{\circ} \mathrm{C}$ respectively.

As an indication from the weight losses test results, the weight loss of SCC concrete with CN fibres was predicted using the weight loss of plain SCC and the fibre volume fraction (Vf) and was expressed as $W l$ in Equations 
Table 2. Comparison of predicted, effectiveness and measured values for weight loss of SCC mixture with and without CN fibres at 4 hours exposure time.

\begin{tabular}{|c|c|c|c|c|c|c|}
\hline \multirow{3}{*}{$\begin{array}{c}\text { CN fibre } \\
\text { (\%) }\end{array}$} & \multicolumn{6}{|c|}{ Weight Loss (\%) } \\
\hline & \multicolumn{3}{|c|}{ Measured } & \multicolumn{3}{|c|}{${ }^{\mathrm{a}}$ Weight effectiveness (\%) } \\
\hline & $200^{\circ} \mathrm{C}$ & $400^{\circ} \mathrm{C}$ & $600^{\circ} \mathrm{C}$ & $200^{\circ} \mathrm{C}$ & $400^{\circ} \mathrm{C}$ & $600^{\circ} \mathrm{C}$ \\
\hline 0.00 & 5.79 & 9.77 & 12.88 & - & - & - \\
\hline 0.05 & 6.76 & 9.88 & 11.15 & 16.75 & 1.13 & -13.43 \\
\hline 0.10 & 5.71 & 9.16 & 10.35 & 12.26 & -4.30 & -19.25 \\
\hline \multirow[t]{2}{*}{0.15} & 5.40 & 8.60 & 11.99 & -6.74 & -11.98 & -20.81 \\
\hline & & Predicted & & \multicolumn{3}{|c|}{ "Residual Error (\%) } \\
\hline 0.00 & 5.81 & 9.79 & 12.85 & 0.33 & 0.22 & -0.23 \\
\hline 0.05 & 6.70 & 9.82 & 11.21 & -0.88 & -0.64 & 0.50 \\
\hline 0.10 & 6.56 & 9.41 & 10.33 & 0.89 & 0.67 & -0.70 \\
\hline 0.15 & 5.38 & 8.58 & 10.21 & -0.37 & -0.24 & 0.13 \\
\hline
\end{tabular}

${ }^{*}$ Residual error $(\%)=($ residual value - measured value $) /$ measured value $\times 100 \%$. ${ }^{a}$ Weight loss effectiveness $(\%)=($ Fibre SCC - Plain SCC $) /$ Plain SCC $\times 100$.

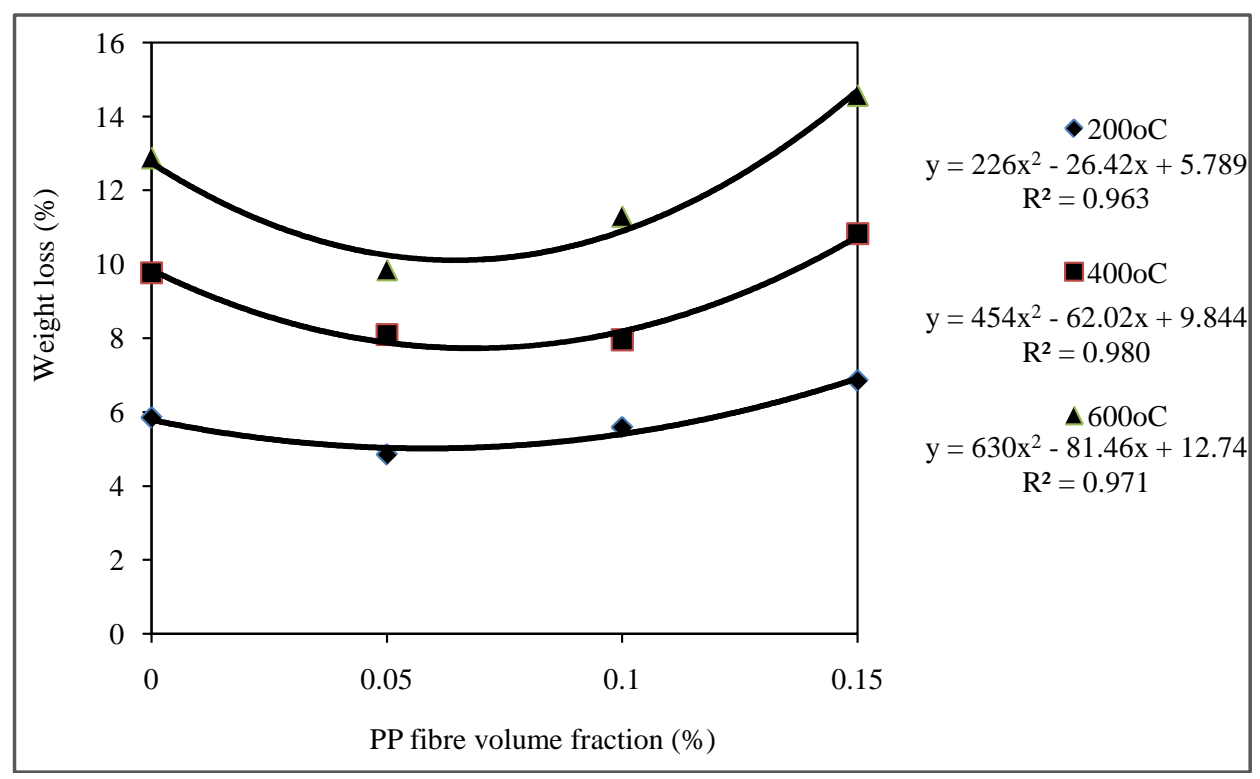

Figure 3. Effect of PP fibre volume on weight loss.

(1)-(3). Substituting $W l=5.81 \%, 9.79 \%$, and 12.85\% in Equations (1)-(3), and applying regression analysis produces correlation coefficients of (0.993), (0.991), and $(0.997)$ for $200^{\circ} \mathrm{C}, 400^{\circ} \mathrm{C}$, and $600^{\circ} \mathrm{C}$ respectively. These variations of the values are about the mean which indicate a goodness of fit between the predicted and the measured values.

$$
\begin{gathered}
W l_{200}=5.809-28.19 V_{f}-207 V_{f}^{2} \\
W l_{400}=9.79+4.82 V_{f}-86 V_{f}^{2} \\
W l_{600}=12.85-40.53 V_{f}+153 V_{f}^{2}
\end{gathered}
$$

The weight losses from the predictions using Equations (1)-(3) agreed favourably with the test results, as in Table 2 the prediction errors ran below $0.88 \%, 0.64 \%$, and $0.70 \%$ for $200^{\circ} \mathrm{C}, 400^{\circ} \mathrm{C}$, and $600^{\circ} \mathrm{C}$ respectively. 


\subsubsection{Hardened Density}

The volume of a mass of concrete changes when it is exposed to elevated temperatures. There is a relation between volume and density, which is the mass per unit volume of concrete. There are many factors that affect the changes in mass density and one of them is thermal expansion. The effects of elevated temperatures on the density of SCC made with granite aggregates, river sand, fly ash, ordinary Portland cement and super plasticizer are shown in Figure 4 and Table 3. The results indicate that below $200^{\circ} \mathrm{C}$ the changes in density are affected by the curing conditions and percentages of CN fibres. Thus, SCC cured in water with different percentages of CN fibres showed a loss in density of about $153,31,0$, and $26 \mathrm{~kg} / \mathrm{m}^{3}$ for $0 \%, 0.05 \%, 0.10 \%$, and $0.15 \%$ CN fibres respectively when heated from $27^{\circ} \mathrm{C}$ to $200^{\circ} \mathrm{C}$; a loss in density of about $243,116,76$, and $121 \mathrm{~kg} / \mathrm{m}^{3}$ for $0 \%$, $0.05 \%, 0.10 \%$, and $0.15 \% \mathrm{CN}$ fibres respectively when heated from $200^{\circ} \mathrm{C}$ to $400^{\circ} \mathrm{C}$, and a loss in density of about $314,178,136$, and $155 \mathrm{~kg} / \mathrm{m}^{3}$ for $0 \%, 0.05 \%, 0.10 \%$, and $0.15 \% \mathrm{CN}$ fibres respectively, when heated from $400^{\circ} \mathrm{C}$ to $600^{\circ} \mathrm{C}$ when exposed to heating for 4 hours.

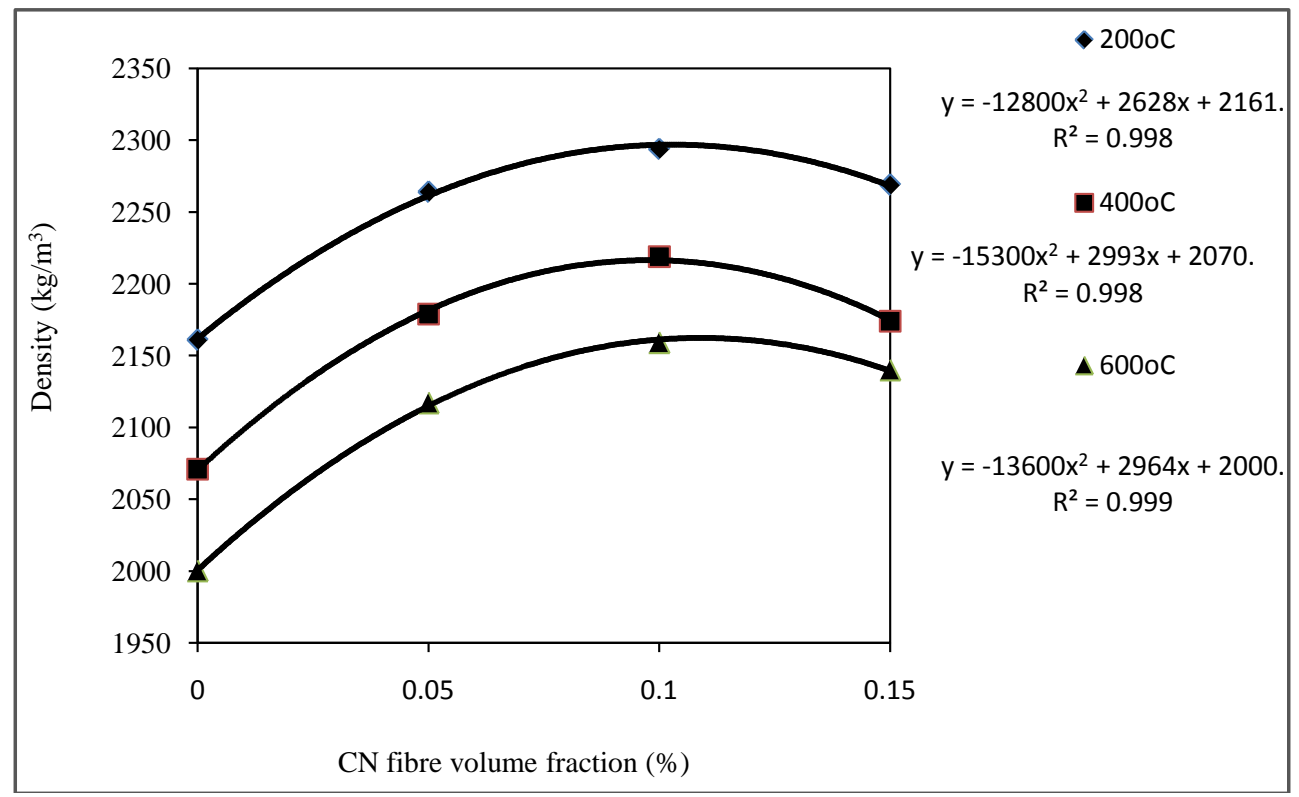

Figure 4. Effect of CN fibre volume on hardened density.

Table 3. Comparison of predicted, effectiveness and measured values for hardened density of SCC.

\begin{tabular}{|c|c|c|c|c|c|c|}
\hline \multirow{3}{*}{ CN fibre (\%) } & \multicolumn{6}{|c|}{ Hardened Density, $\left(\mathrm{kg} / \mathrm{m}^{3}\right)$} \\
\hline & \multicolumn{3}{|c|}{ Measured } & \multicolumn{3}{|c|}{ 'bensity effectiveness (\%) } \\
\hline & $200^{\circ} \mathrm{C}$ & $400^{\circ} \mathrm{C}$ & $600^{\circ} \mathrm{C}$ & $200^{\circ} \mathrm{C}$ & $400^{\circ} \mathrm{C}$ & $600^{\circ} \mathrm{C}$ \\
\hline 0.00 & 2161 & 2071 & 2000 & - & - & - \\
\hline 0.05 & 2264 & 2179 & 2117 & 6.15 & 5.22 & 5.85 \\
\hline 0.10 & 2294 & 2219 & 2159 & 5.00 & 7.15 & 7.95 \\
\hline \multirow[t]{2}{*}{0.15} & 2269 & 2174 & 2140 & 5.00 & 4.97 & 7.00 \\
\hline & & Predicted & & \multicolumn{3}{|c|}{ "Residual Error (\%) } \\
\hline 0.00 & 2161 & 2070 & 2000 & 0.00 & -0.05 & 0.00 \\
\hline 0.05 & 2260.4 & 2181.4 & 1468.2 & -0.16 & 0.11 & -30.65 \\
\hline 0.10 & 2295.8 & 2216.3 & 936.4 & 0.08 & -0.12 & -56.63 \\
\hline 0.15 & 2267.2 & 2174.7 & 404.6 & -0.08 & 0.03 & -81.09 \\
\hline
\end{tabular}

${ }^{*}$ Residual error $(\%)=($ residual value - measured value $) /$ measured value $\times 100 \%$. ${ }^{\mathrm{b}}$ Density effectiveness $(\%)=($ Fibre SCC - Plain SCC) $/$ Plain SCC $\times$ 100 . 
The change in mass density of the SCC with CN fibres versus temperature appears in Table 3 and Figure 4, showing that the densities of plain concrete were 2161,2071 and $2000 \mathrm{~kg} / \mathrm{m}^{3}$ at $200^{\circ} \mathrm{C}, 400^{\circ} \mathrm{C}$, and $600^{\circ} \mathrm{C}$. The concrete with CN fibres provided an improvement at each volume fraction until $0.10 \%$ of $\mathrm{CN}$ fibre. The improvement, as the density-effectiveness in Table 3 indicates, is 6.15\%, 5.22\%, and 5.85\% for the 0.05\% fraction, $5.0 \%, 7.15 \%$ and $7.95 \%$ for the $0.10 \%$ fraction, and $5.0 \%, 4.97 \%$ and $7.0 \%$ for the $0.15 \%$ fraction at $200{ }^{\circ} \mathrm{C}$, $400^{\circ} \mathrm{C}$, and $600^{\circ} \mathrm{C}$ respectively, being a small reduction compared to the maximum loss in density for the $0.15 \%$ fraction. The density reductions of the SCC concrete with CN fibres ranged from $6.15 \%$ to 5.0\%, 5.0\% to 7.95\%, and $5.0 \%$ to $7.0 \%$ for the volume fractions of $0.05 \%$ to $0.15 \%$, and temperatures $200^{\circ} \mathrm{C}$ to $600^{\circ} \mathrm{C}$ respectively.

Shneider (1982) [18] indicated a loss in density of about $0.1 \mathrm{~g} / \mathrm{cm}^{3}$ when the heated temperature was between $20^{\circ} \mathrm{C}$ to $150^{\circ} \mathrm{C}$ and $2.21 \mathrm{~g} / \mathrm{cm}^{3}$ at $600^{\circ} \mathrm{C}$ for concrete with a limestone aggregate. As an indication from the test results of the changes in mass density, the density of SCC concrete with CN fibres was predicted using the density of plain SCC and the fibre volume fraction (Vf) and was expressed as $\rho$ in Equations (4)-(6). Substituting $\rho=$ 2161, 2070, and $2000 \mathrm{~kg} / \mathrm{m}^{3}$ in Equations (4)-(6), and applying regression analysis gave correlation coefficients of (0.998), (0.998), and (0.999) for $200^{\circ} \mathrm{C}, 400^{\circ} \mathrm{C}$, and $600^{\circ} \mathrm{C}$ respectively. These variations of the values are about the mean which indicate a goodness of fit between the predicted and the measured values.

$$
\begin{aligned}
& \rho_{200}=2161+2628 V_{f}-12800 V_{f}^{2} \\
& \rho_{400}=2070+2993 V_{f}-15300 V_{f}^{2} \\
& \rho_{600}=200+2964 V_{f}-13600 V_{f}^{2}
\end{aligned}
$$

The density predictions using Equations (4)-(6) agreed favourably with the test results, as in Table 3 the prediction errors run below $0.16 \%, 0.12 \%$, and $81.09 \%$ for $200^{\circ} \mathrm{C}, 400^{\circ} \mathrm{C}$, and $600^{\circ} \mathrm{C}$ respectively.

\section{Conclusions}

Based on the results presented in this research the following conclusions were drawn:

- Fresh properties of SCC with CN fibres indicated that a $0.10 \%$ by volume is the optimum to mitigate explosive spalling of SCC. Also, it showed that an excess of fibre with a chemical reaction was found to absorb water because of the wood properties of $\mathrm{CN}$ fibre in the mixture.

- The minimum weight loss was cited for $0.10 \% \mathrm{CN}$ fibre which indicated the optimum that could be stood at elevated temperatures compared to the other mixtures.

- As the temperature increased the weight loss also increased. The addition of CN fibres to the design mix reduced the weight loss at $0.10 \% \mathrm{CN}$ fibres although generally the addition of fibres caused the weight loss to increase.

- The change in mass density with and without the addition of fibres to the SCC indicated that the maximum density was at $0.10 \% \mathrm{CN}$ fibres. The density increased with the increase in the fibre content until $0.1 \%$ volume fraction of the mixture after which it decreased.

The regression models of the fresh and thermo gravimetric properties were developed for SCC including CN fibres to accurately predict the weight loss, and hardened density at elevated temperatures.

\section{Acknowledgements}

The research described and conducted in this paper was executed at the Civil Engineering Department, at Universiti Tenaga Nasional (Uniten), and AL Hussien Bin Talal University, and was funded by the Ministry of Science, Technology and Innovation (MOSTI), E-Science Grant (03-02-03-SFO140. Many thanks to Eng. Mothaffer N. S. AL-Qadi for his help in this research.

\section{References}

[1] Engineer J. Singapore (1976) Coconut Fiber in Concrete. Building and Materials, 3, 51-54.

[2] Khedari, J., Suttisonk, B., Pratinthong, N. and Hirunlabh, J. (2006) New Lightweight Composite Construction Materials with Low Thermal Conductivity. Construction and Building Materials, 20, 673-678.

[3] Reis, J.M.L. (2006) Fracture and Flexural Characterization of Natural Fiber-Reinforced Polymer Concrete. Construction and Building Materials, 20, 673-678. 
[4] Guth, D. (1998) Development and Evaluation of an Air Permeability Test Device for Concrete. Ph.D. Thesis Submitted to the Department of Civil Engineering, North Carolina State University, Raleigh, NC, 230.

[5] Liu, X., Ye, G., Deschutter, G., Yuan, Y. and Taerwe, L. (2008) On the Mechanism of Polypropylene Fibers in Preventing Fire Spalling in Self-Compacting and High-Performance Cement Paste. Cement and Concrete Research, 38, 487-499. http://dx.doi.org/10.1016/j.cemconres.2007.11.010

[6] Lia, C.-Z., Feng, N.-Q., Li, Y.-D. and Chen, R.-J. (2005) Effects of Polyethleneoxide Chains on the Performance of Polycarboxylate-Type Water-Reducers. Cement and Concrete Research, 35, 867-873. http://dx.doi.org/10.1016/j.cemconres.2004.04.031

[7] Hertz, K.D. and Sørensen, L.S. (2005) Test Method for Spalling of Fire Exposed Concrete. Fire Safety, 40, 466-476. http://dx.doi.org/10.1016/j.firesaf.2005.04.001

[8] Fares, H., Noumowe, A. and Remond, S. (2009) Self-Consolidating Concrete Subjected to High Temperature Mechanical and Physiochemical Properties. Cement and Concrete Research, 39, 1230-1238. http://dx.doi.org/10.1016/j.cemconres.2009.08.001

[9] Fares, H., Remond, S., Noumowe, A. and Cousture, A. (2010) High Temperature Behaviour of Self-Consolidating Concrete Microstructure and Physicochemical Properties. Cement and Concrete Research, 40, 488-496. http://dx.doi.org/10.1016/j.cemconres.2009.10.006

[10] ASTM Standard C 150 (2006) Specification for Ordinary Portland Cement. Annual Book of ASTM, Standard, Section 04 Construction, Volume 04.02 Concrete and Aggregate, ASTM International, West Conshohocken, PA. www.astm.org.

[11] ASTM C 33-03 (2006) Specification for Concrete Aggregate. Annual Book of ASTM, Standard, Section 04 Construction, Volume 04.02 Concrete and Aggregate, ASTM International, West Conshohocken. www.astm.org

[12] ASTM C 618-05 (2006) Specification for Coal Fly Ash and Raw or Calcined Natural Pozzolan for Use in Concrete. Annual Book of ASTM, Standard, Section 04 Construction, Volume 04.02 Concrete and Aggregate, ASTM International, West Conshohocken. www.astm.org

[13] ASTM C494/C494M-05a (2006) Specification for Chemical Admixture for Concrete. Annual Book of ASTM, Standard, Section 04 Construction, Volume 04.02 Concrete and Aggregate, ASTM International, West Conshohocken. www.astm.org

[14] BS 3148 (1980) Methods of Test for Water for Making Concrete. British Standard Institution, London.

[15] PCA, Portland Cement Association (2002) Concrete Information. IS 532.

[16] ASTM C 1611/C 1611M-05 (2006) Test Method for Slump Flow of Self-Consolidating Concrete. Annual Book of ASTM, Standard, Section 04 Construction, Volume 04.02 Concrete and Aggregate, ASTM International, West Conshohocken. www.astm.org

[17] EFNARC (2002) Specification and Guidelines for Self-Compacting. Concrete, Association House, Surrey, UK. www.efnarc.org

[18] Schneider, U. (1982) Behaviour of Concrete at High Temperatures. Report to RILEM Committee 44-PHT, The Hague, April, 72.

[19] Harmathy, T.Z. and Berndt, J.E. (1973) Thermal Properties of Selected Masonry Unit Concretes. Journal of the American Concrete Institute, 70, 132-142. 